\title{
Specification of urban planning regulation in a sustainable city
}

\author{
E. Salehi \\ Faculty of Environment, University of Tehran, Iran
}

\begin{abstract}
The city form is shaped by a set of decisions made by residents. It must be controlled or otherwise chaos would rule the whole city system; that is why all societies need codes and regulations to control decisions and correct and facilitate their performance so that society can live securely knowing that they can expect others to follow the same regulations.

One method for regulating peoples' behaviour is the use of urban planning codes and regulations control that may have spatial and physical reflection. Sustainable development can lead to equity over time, which certainly can be considered as the goal of such codes and regulations. In fact, composing urban codes and regulations is a means of achieving the goals of sustainable development and ensure the formation of sustainable residency.

While studies on codes and regulations considered as the criteria for enforcing in a case study, (a city in Iran), methodologies like comparative researching and utopia typology showed that present codes and regulations could not be tailored to urban planning and its sustainable development.
\end{abstract}

Key words: codes, regulations, urban planning, sustainable development, sustainable city, law, natural environment, urban management, citizen, equity.

\section{Introduction}

Cities are the main source of human societies' activities. In these spaces conflicts between human and nature reach a climax. That is why the creation of a 'good and sustainable' relationship between urban society and the natural and built environment is a must.

In the past, the trend of change of evolution and the growth of cities was gradual and facilities, tools diversity, building material and technology as well as tastes, were limited; cultural and conventional systems acted well and the results 
were of cities with sustainable and harmonic forms and appearance [1]. However, nowadays everyone has this general feeling that most city districts are undesirable and unsustainable.

Codes and regulations of urban planning, define physical and spatial system of cities and so influence all factors that find identity as urban activities (such as socio-economic and cultural activities, etc.). In fact, they determine and confine their physical and spatial form. Quality and quantity of urban planning codes and regulations of each city directly reflects on its urban activities' quality and quantity.

In the case where all the potential roles of urban planning codes and regulations could be implemented in an efficient framework, considering extent and importance of each, the formation of the 'sustainable city' can be secured by support of other completing components (if urban planning codes and regulations have a sustainability specification).

\section{Theoretical frameworks}

The theoretical framework of this article is a summary of synthesizing numerous ideas in an analytical and theoretical model which was prepared as a guide to study.

In this framework, In Louis Worth's point of view, "a city is a permanent, compact and relatively large settlement in which many people live adjacent to each other" [2]. The quality of these people lives has a direct relation with the quality of environment and city form.

In a theory of Edmond Bacon's, "collective decision of habitants in each city, make its form ..." [3]. In this regard, Lynch points out factors of people such as households, institutions, firms, constructor, investors, etc. to mention that as each of them has its own likes, interests, needs and tastes, in the case of not controlling leads to disorder and chaos because of expanded and numerous ranges of conditions [4].

Thus, "a city must be regulated. Because city life with chaos and without regulatory and doable mechanisms will decline..." [5].

Base on the fact, nowadays "to control peoples' decisions and correct operation, all societies need rules and regulations until people can live and work securely and know that they can expect others to obey the same regulations" [6].

Since that part of peoples' decisions which has spatial, physical and functional reflection in a city can be controlled by urban planning codes and regulations, it is necessary to "determine the role of urban planning codes and regulations in a way that preserve interests and ensure the wellbeing of city habitants [now and in the future]" [7].

How can such a condition be provided? According to what Lynch said, to provide these conditions a comprehensive vision of a desirable situation of a good and sustainable city is needed. He had an exhaustive theory in this regard that can be considered as an idea and sustainable theory for a city form because it is not restricted to a society or a specific period of time. But distance of this 'theory' and similar ones to 'practice' is a lot due to their generality. 
This article introduces a mechanism to convert 'idea to code' as a bridge of converting 'idea to action' (idea $\rightarrow$ code $\rightarrow$ action) through which goals and hopes of a good and sustainable city could be reached.

\section{Roles of codes and regulations in sustainable development}

The concept of sustainable development can be expanded to actual thoughts of 'equity' concept both in width and length of time (Figure 1).

In each historical and time section, therefore, to create coherence and maintain balance, it is required to remove or prevent incoherence and imbalance factors and contexts in a plan, and enact efficient codes and regulations to maintain and promote sustainable condition during time.

In fact, the role of codes and regulations which were efficiently enacted to reach goals and hopes of sustainable development, in case of efficient implementation, ensure maintenance and improvement of coherence and balance in using resources during time.

- Keeping balance among all present community (equity in width of time)

- Keeping balance among society's generation (equity in length of time)

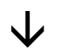

- Preventing confiscation of resources by a group (abusing rights of other groups)

- Preventing confiscation of resources by a generation (abusing rights of other generations)

- Evidence on lack of balance in width of time:

- Lack of balance between countries in north and south in international level

$\bigcirc \quad$ Lack of balance between urban and rural development in national level

- Lack of balance between different districts of a city in local level

- Evidence on lack of balance in length of time:

○ Extensive exploitation of limited natural resources by a generation

forests

- mineral resources

$\downarrow$

-Role of plans and programs:

Determining methods and mechanisms to create balance in width of time

- Role of codes and regulations

Determining methods and mechanisms to ensure sustainability of balance in length of time

Figure 1: Declaration of concept of equity and sustainable development and the role of plans and codes. 


\section{Urban planning regulations}

Urban planning codes and regulations have both legal and urban planning aspects. Thus both legal and urban planning philosophy, emphasize this point that: a city must be regulated because urban life in chaos without enforceable legal and urban planning mechanisms will decline, and cannot remove interest conflicts and meet its needs.

Law and urban planning are complementary arenas in regulating context and the physic of urban society (Figure 2 ). In the case where there will be a good understanding of their roles and their usage to reach goals of urban society, 'complete discipline and integration of human built environment' can be expected as a synthesis and common product of two mentioned arenas.

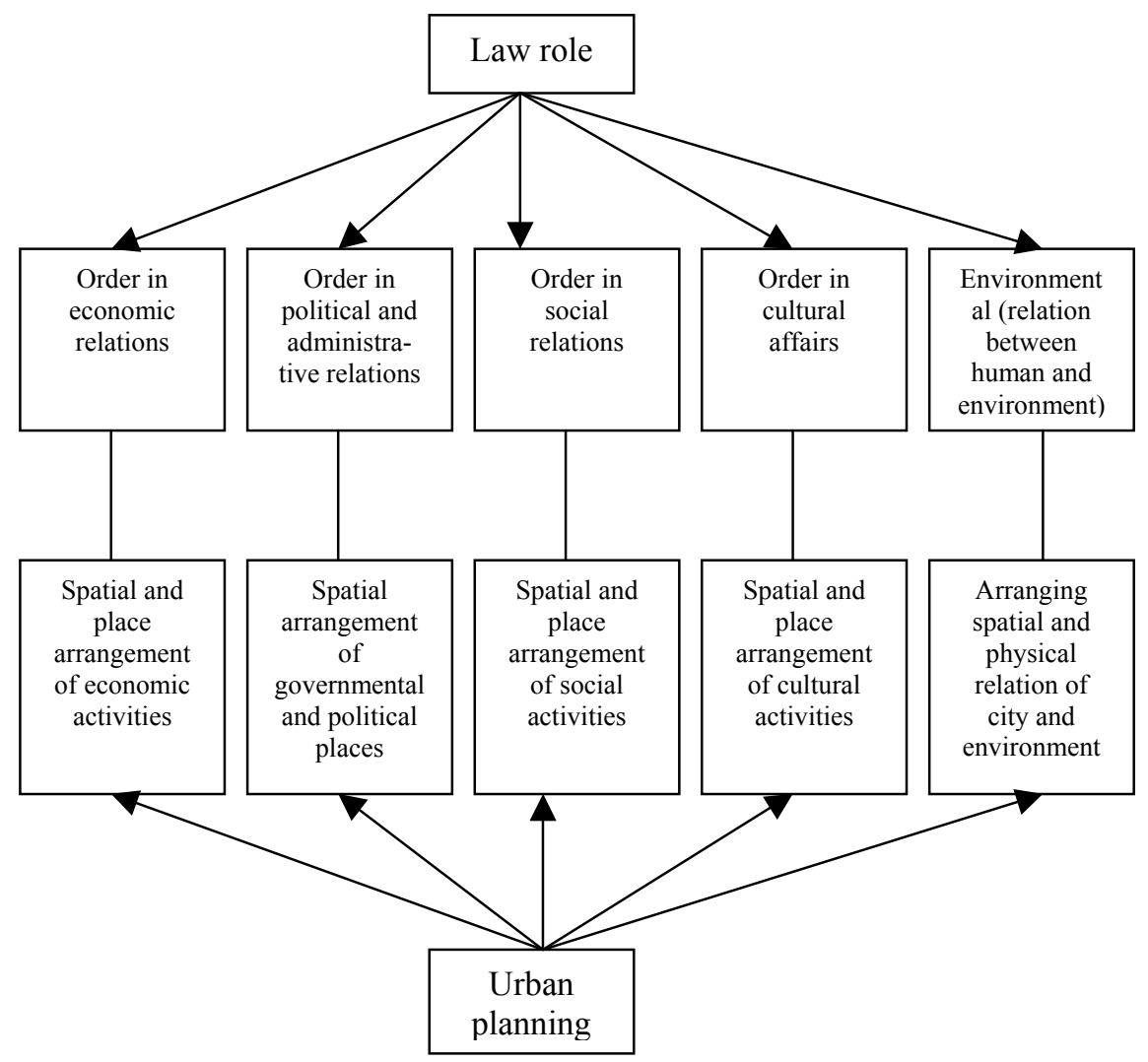

Figure 2: 'Law' and 'urban planning', two complementary arenas of sustainable settlement [8].

As environmental and urban planning codes and regulations are considered as an interface of urban planning and legal systems, on the one hand they are a transfiguration of environmental and urban planning goals and hope to 
'regulate spatial and physical conditions of providing numerous, diverse, public and private urban requirements' and on the other hand are a transfiguration of legal goals and hopes to 'regulate conditions for providing coherence among numerous, diverse, public and private interests' of society (Table 1). Therefore 'practical ability' of urban planning codes and regulations can be used as a mechanism to convert 'ideas to action'.

Urban planning codes and regulations, based on its role and importance, can lead to the implementation of 'a good and sustainable city' if efficiently legislated and enforced. The importance of the subject attributed from here.

Table 1: $\quad$ Comparative conclusion of legal and urban planning roles.

\begin{tabular}{|c|c|}
\hline $\begin{array}{c}\text { Law expert point of view about } \\
\text { city }\end{array}$ & $\begin{array}{l}\text { Urban planner point of view about } \\
\text { city }\end{array}$ \\
\hline $\begin{array}{l}\text { - City is the most concentrated mass } \\
\text { of numerous, diverse and conflicted } \\
\text { interests of human being [9] }\end{array}$ & $\begin{array}{l}\text { - City is the most concentrated arena } \\
\text { of emanating numerous, diverse and } \\
\text { conflicted needs of human being [10] }\end{array}$ \\
\hline - Thus city is a legal arena [8] & - Thu \\
\hline $\begin{array}{l}\text { - Rights are the most important and } \\
\text { main mechanism for peaceful } \\
\text { arrangement of citizens' interests }\end{array}$ & $\begin{array}{l}\text { - Urban planning is the most } \\
\text { important and main mechanism for } \\
\text { arranging methods to provide citizens } \\
\text { needs [12] }\end{array}$ \\
\hline $\begin{array}{l}\text { - Prediction of friction surfaces of } \\
\text { conflicted socio-economic interests } \\
\text { and legislating laws and regulating } \\
\text { judicial and registration procedures } \\
\text { consider as some of legal } \\
\text { arrangements to regulate interests } \\
\text { peacefully }\end{array}$ & $\begin{array}{l}\text { - Prediction of socio-economic } \\
\text { tendencies and urban society, spatial } \\
\text { and physical planning and design are } \\
\text { some of the arrangements to regulate } \\
\text { provision of city and citizens needs }\end{array}$ \\
\hline $\begin{array}{l}\text { - Summery of legal philosophy and } \\
\text { goal: } \\
\text { Regulating public and private } \\
\text { interests through judicial and } \\
\text { registration arrangements }\end{array}$ & $\begin{array}{l}\text { - Summery of urban planning } \\
\text { philosophy and goal: } \\
\text { Regulating public and private needs } \\
\text { through judicial and physical } \\
\text { arrangements }\end{array}$ \\
\hline $\begin{array}{l}\text { - Result of good role play of law in } \\
\text { city: } \\
\text { Formation of good citizenship } \\
\text { relation }\end{array}$ & $\begin{array}{l}\text { - Result of good role play of urban } \\
\text { planning in city: } \\
\text { Formation of good judicial and } \\
\text { physical relation of cit }\end{array}$ \\
\hline \multicolumn{2}{|c|}{$\begin{array}{c}\text { All aspect of needs regulation by urban planning and interests' regulation by } \\
\text { law are complementary in provision of general order in society and its } \\
\text { sustainability }\end{array}$} \\
\hline
\end{tabular}

Salehi, 2003 [8]. 


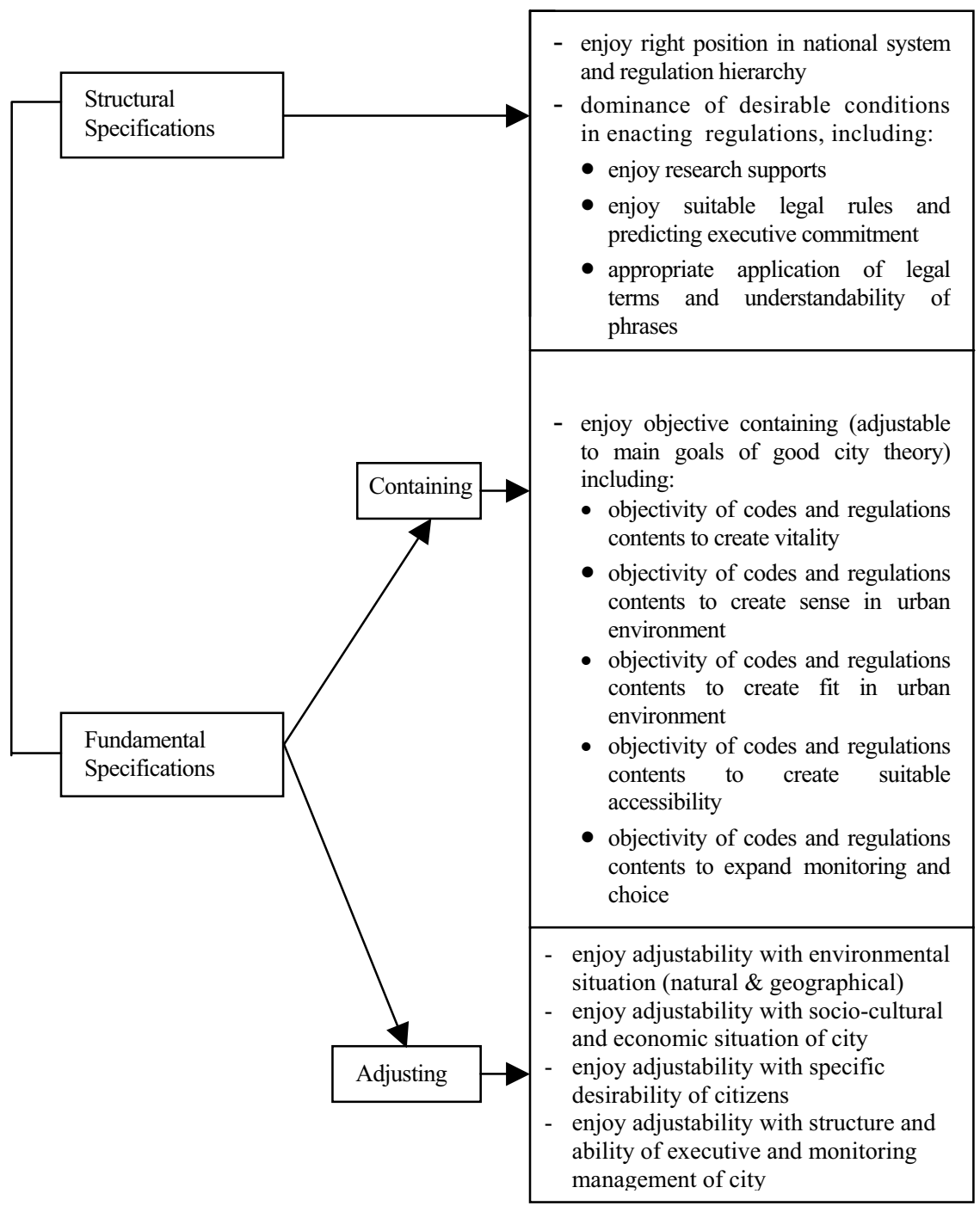

Figure 3: General specification of good and sustainable type of urban planning codes and regulations.

Since any discussion about environmental planning and design (including urban planning codes and regulations) is not complete without an understanding of the final goal, to compare characteristics of good and sustainable type of urban planning codes and regulations with urban planning codes and regulations enforced in Iranian cities, a utopia typology of good and sustainable urban planning codes and regulations is carried out.

Urban planning codes and regulations do not have an initial desirability but in case they have specifications of desirability and sustainability, they can be tools 
to implement goals and ideals of a sustainable city. Related specifications consist of seven general and several detailed specifications that were synthesized and analyzed in this research (Figure 3).

Specifications can be divided in two categories: structural (mainly legal) and fundamental (mainly urban planning). One of the most important specifications among those mentioned is 'content objectivity of codes and regulations'. Mentioned main goals in 'theory of good form of city' [4] assessed as 'initially good and sustainable' due to their desirability in all durations and generations. Therefore axial goals can be the final goals of all kinds of tools related to formation of sustainable urban environment such as sustainable urban planning codes and regulations.

In other word, codes and regulations are not goals themselves but are tools for the implementation of 'a good and sustainable city' and so can play a good role if they are 'good tools'. In this study after analyzing different aspects of this role, specifications of good and sustainable urban planning codes and regulations are synthesized and classified.

It must be noted that, axial goals of good form of city theory, including vitality, sense, fit, access, monitoring and choice, efficiency and justice, in concept that a good and sustainable city is introduced in this article is considered as 'initially good' and must be the goal of all tasks and choices of urban planners (as contained in the specifications). Certainly, urban planning wants it everywhere and actively seeks it. So urban planning codes and regulations, also (as a mechanism for action) are considered as an essential tool to implement it.

On the other hand, paying attention to adjusting the specifications of urban planning regulations, ensure its sustainability and compatibility with local conditions that goals will come off in it (Figure 4).

As a study in the University of Tehran, after concluding good and sustainable specifications of a city, the specifications of urban planning codes of a sample city (Tehran) were compared and analyzed.

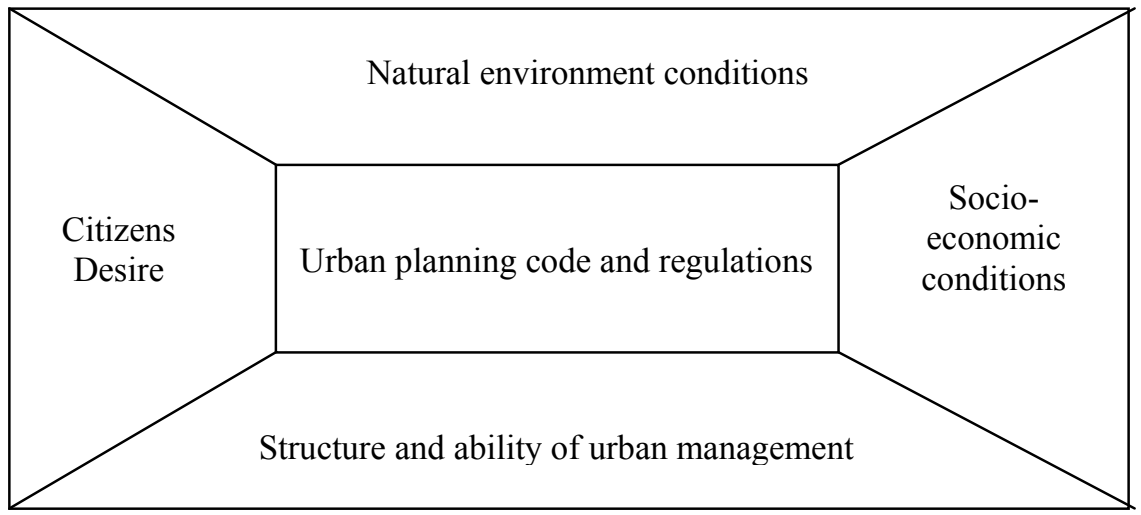

Figure 4: Adjusting specification of urban planning codes and regulations [8]. 
Considering the fact that the efficiency of enforced codes and regulations evaluated are not done well, it cannot be expected to implement goals and utopias. Since the dominant pattern of enforced urban planning codes and regulations in Tehran are almost common in all other cities and often are similar, they act the same all over the country.

\section{Conclusions}

Urban planning regulations consider the most important dialect, tool and art of urban planning and law, ensuring sustainable provision of needs and protection of interests (public and private) in settlements. In other words, if urban planning regulations legislate efficiently and are enforced effectively, they can lead to a good sustainable city. It is said as an analytic- conceptual model (Figure 5) regulating and guiding people's decisions and finally formation of good and sustainable spatial and physical relation, on the one hand, and good and sustainable citizen relationship on the other hand, can be provided.

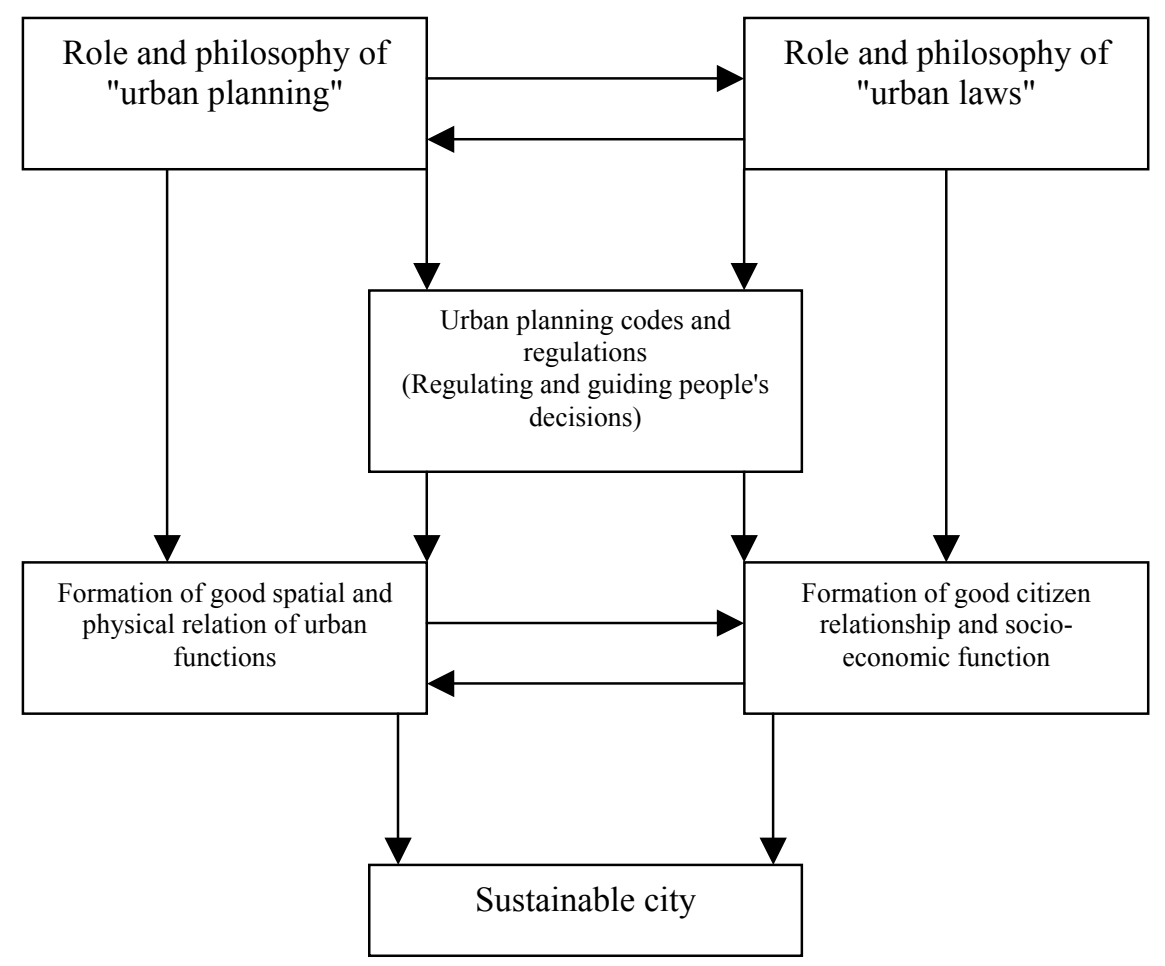

Figure 5: Analytic and conceptual model of role and position of urban planning regulations in the formation of a sustainable city. 


\section{References}

[1] Morris, J (1989) "History of urban form" Translated by Rezazedh, University Elme \& Santa.

[2] Kostof, Spiro (1991) " The city shaped" Thames and Hudson.

[3] Bacon, Edmond, (1997) "Design of cities", translated by Taheri, Ministry of urban planning \&housing.

[4] Lynch, Kevin (1981) "A theory of good city form", Cambridge, Mass MIT Press.

[5] Barrie, Sherman (1988), " Cities fit to live in, themes and variations ", ATZ, publishers grate fully.

[6] Galbraith S, (1998) "Building and Land Management law for student" Butter worth and Hellmann Oxford.

[7] Giedion, S (1986)" Raum, zeit, Architektur" Translated in Persian with Muzayyini Scientific \& Cultural Publication Company.

[8] Salehi, Esmaile (2003) "Analysis of role urban planning regulation in forming good city" University of Teheran.

[9] Lioyd, D (1977) "The idea of Law", penguin books.

[10] Douglas LAN, (1983),"The urban Environment" Edward Arnold, London.

[11] Green, Kate and Cursley, Joe (1999)"Land Law" Pal rage Law Masters.

[12] Brain, Edward and Torrent (Ed) (1999) "Sustainable housing principle and practice" E \& Fnspon Taylor. 